Journal of Economics and Behavioral Studies

Vol. 5, No. 6, pp. 385-397, June 2013 (ISSN: 2220-6140)

\title{
Comparative Analysis of the Determinants and Behaviour of Investment Demand between South Africa and Zimbabwe
}

\author{
Sambulo Malumisa \\ Large Business Centre South African Revenue Service Rivonia, South Africa \\ malumisas@gmail.com
}

\begin{abstract}
The study investigates the determinants of private investment in South Africa and Zimbabwe employing annual data over the 1980-2010 periods. The influence of gross domestic product (GDP), government debt, inflation, and interest rate policies are considered. Applied vector autoregressive and error correction models are used to estimate long- and short-run relationships among variables. The results suggest that GDP has a positive effect on private investment. Government debt has a crowding out effect on private investment, and inflation is shown to negatively affect investment. Increases in interest rates discourage private investment in South Africa
\end{abstract}

Keywords: Private Investment, South Africa, Zimbabwe, Co-integration, error correction

\section{Introduction}

In every economy, the development and growth of the private sector is essential. From organizations to economies, all have sought to improve the performance of the private sector. Investment plays a pivotal role in economic growth. As such, it is the value of machinery, plants, and buildings that are bought by firms for production purposes. Investment plays major macroeconomic roles, including;

a. Contributing to current demand of capital goods, thus it increases domestic expenditure, consequently enlarging the production base (installed capital), and increasing production capacity.

b. Modernizing production processes, improving cost effectiveness and;

c. Incorporating international excellent innovations and quality standards, bridging the gap with more advanced countries and helping exports and an active participation to international trade.

Optimal investment levels result in improved national output and the creation of jobs and thus translate into better living standards for the populace. It is of interest to examine the behaviour of private investment activity in African countries because it is a key factor underlying economic growth in these countries. The findings of such studies also have teaching and research values to economists and can prove a useful guide to policymakers. This is reinforced by the fact that to date, empirical research in this area has been limited, largely because data on private investment in African countries have been scarce or unreliable. Therefore, a study of this nature enables policymakers to make informed decisions.

In general, many of the studies have attempted to identify the evolution of investment (fixed capital formation) focused on single countries. Very few have focused on a multiple of countries. Of these, authors like Sioum (2002) focused on Southern Africa. It is interesting to compare the investment behaviour of private firms in two or more different African countries. This is because changes in economic environments usually affect firms differently especially when they are operating in different markets and they are experiencing different types of regulations, as is the case in South Africa (RSA) and Zimbabwe. Hence, this study investigates the determinants of private investment in South Africa and Zimbabwe, employing annual data over the period 1980-2010. The study also aims to understand investment behaviour in these two countries by including important proxies of uncertainty namely macroeconomic and socio political stability. As such, the study is also of significance as it confers with the risks associated with low investment levels. With Zimbabwe's unemployment rate currently topping 70\% and RSA's above 25\% (Stats SA, 2013), investment friendly policies will go a long way to address unemployment and alleviating poverty. Furthermore, RSA faces a growing budget deficit and one way to reign on the deficit is to nurture policies that encourage investment hence GDP growth and ultimately low deficit levels. Low deficit will ensure that the 
economy borrows as well from the international community at favourable terms, thereby maintaining the trend of GDP growth.

The desire to improve the performance of the private sector has shaped the macroeconomic policies in these two economies for some time, RSA and Zimbabwe still face some challenges in addressing factors which lead to desirable and sustainable levels of private investment. RSA is Zimbabwe's most important trading partner and also a diversified economy in the African continent. Investment rates in RSA's physical capital have shown a downward trend for a while. Average investment stood at $22 \%$ in the 1980 s and then dropped to $16 \%$ in the 1990s. The centrality of investment in physical capital stock, as a determinant of economic growth, makes such sub-optimal rates a cause for concern. As part of other challenges, emanating from suboptimal investment has been the high unemployment rate. The country's ability to address these problems and challenges is closely linked to the attainment of high investment levels. Zimbabwe's inflation skyrocketed to 200 million\% in 2008. Under conditions of very low investment levels and negative GDP growth, a lot needs to be done to restore confidence in the investment turf. Private sector fixed capital formation has shown marginal fluctuations in real terms, though consistently low as a proportion of GDP. It was $11 \%$ during $1969-79,10 \%$ from $1980-84$ and $12 \%$ during $2000-2008$. The rest of the paper is arranged as follows; section 2 focuses on macroeconomic developments about the determinants and behaviour of private investment in both countries. Section 3 presents the literature. Data and Methodology are presented in section 4 . Section 5 presents results while section 6 concludes.

Macroeconomic Developments in RSA and Zimbabwe: RSA, with a gross domestic product (GDP) of US $\$ 408$ billion in 2011 (World Bank, 2013) is the economic powerhouse of Africa. Over the years, as one of the biggest challenges facing this Sub-Saharan African economy has been the composition of investment necessary to induce high growth. The country has to date adopted a number of macroeconomic policies necessary to encourage high investment. Low levels of investment in the country have been identified repeatedly as cause of suboptimal economic growth rates. Investment as represented by gross fixed capital formation (GFCF) averaged $26.4 \%$ of GDP in the 70 s. It then dropped to $22 \%$ in the 1980 s and dropped further again to $16 \%$ of GDP in the $90 \mathrm{~s}$. As for the twenty-first century, private investment recovered with the manufacturing sector emerging as a leader in investment rates in a number of its sub sectors from the 1990s. Current GFCF as a percentage of GDP hover around the $20 \%$ mark despite the recent global economic crisis of 2008 (World Bank, 2013). Triggering the low investment levels and GDP growth rates in Zimbabwe has been the tough economic environment. In the years 1982 to 1985, Zimbabwe's fixed investment by the public sector exceeded that of the private sector. At one time investment did contribute to efficiency gains in the major sectors, and ultimately growth, when channelled towards improvement and enhancement of productive and technological capacities. This was most evident in the manufacturing and mining sectors, where substantial investments were made in new capital-intensive techniques after trade and investment liberalization measures were introduced by the government in the early $90 \mathrm{~s}$. At that time, the investment rate in the economy had attained levels regarded as commensurate with rapid economic growth, averaging around $22-23 \%$ of GDP (Jenkins, 1998).

Zimbabwe also adopted numerous policies over the years to enhance investment. One such policy was the Economic Structural Adjustment Programs (ESAP), which saw an increase in investment notably in 1993 at around $25 \%$ of GDP. However, ESAP failed where it counted most: it did not lead to a substantial and sustained increase in investment. Though the drafting of ESAP may have owed more to the World Bank and International Monetary Fund (IMF), the authorities did not restrain sufficiently on public expenditure, thereby crowding out private investment and generating inflation. Even after adopting additional economic recovery programs over the past few years, investment still remains low. Investment as a percentage of GDP fell from 16\% in 1999 to 5\% in 2008. The low level of GDP at US\$9 billion in 2011 is also attributable to such low investment rates. The figure below shows Zimbabwe's general decline in GFCF. The figure above shows Zimbabwe's general decline in GFCF. The economy, unlike neighbouring RSA, experienced declining growth as a result of low investment induced by unstable macroeconomic phenomena. The pointers to low investment were the depreciating dollar, negative real interest rates, huge government debt and skyrocketing inflation. We can also deduce from the figure that investment was high especially in the early 80s before the adoption of economic reform and even in the early to mid 90s during the phase of ESAP. Afterwards, economic growth took on the negative. A host of policy measures were adopted to remedy the situation 
though not much investment growth was realised by these initiatives. Also confirming the low investment levels were the unstable and uncertain political environment discouraging investors from making conceited efforts in increasing investment related activities. By contrast, RSA's experience in GFCF has seen sustainable growth. From Figure 2 below, we can deduce that though the trend had been declining, from the 80 s to the 1990s, there was recovery afterwards. The investment friendly interest rates, stable exchange rate, low government debts and well-contained inflation rate are some of the factors, which played significant roles to bolster investment. The outcome of such has been depicted in positive economic growth over these years, which culminated to avoiding severe effects of the 2008-09 global financial crises.

Figure 1: GFCF in Zimbabwe 1980-2008

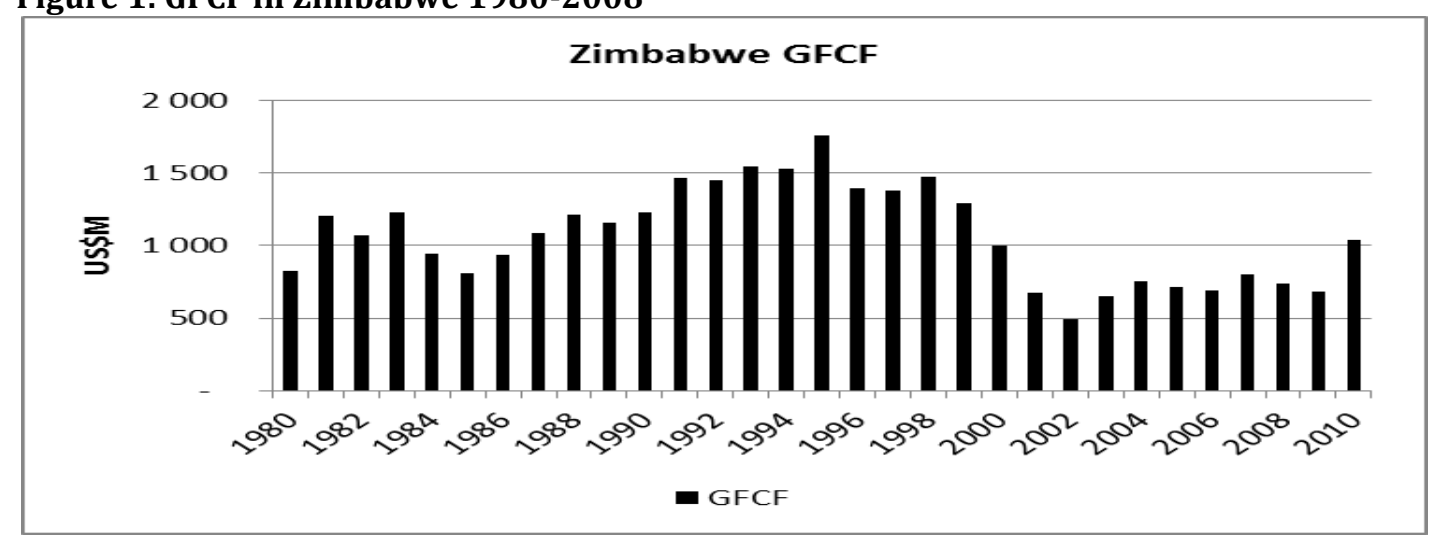

Source: IMF (2010); WRI (2010)

Figure 2: GFCF in RSA 1980-2008

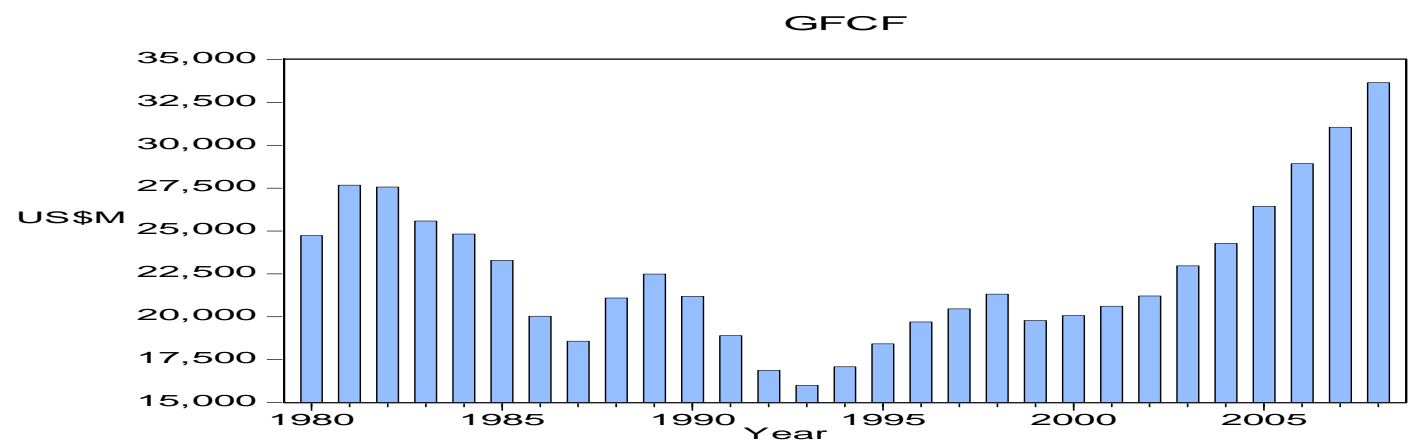

Source: IMF (2010); WRI (2010)

\section{Literature Review}

In general, the literature on investment tries to explain how firms, given a set of motives, select their optimal capital stock and how the selected optimal capital stock is affected by variations in the degree of uncertainty about future prospects. Some theories that focus on the accumulation of fixed capital by the private sector have been based on models formulated for industrialized and developed economies. The main theories that explain determinants of investment behaviour are the expected profits theory, accelerator theory, and neoclassical theory. Jorgenson (1971) and others have formulated the neoclassical approach to explain determinants of investment behaviour. In this approach, the desired or optimal capital stock is proportional to output and the user cost of capital (which in turn depends on the price of capital goods, the real rate of interest, the rate of depreciation and the tax structure). Similarly, the "Q" theory of investment associated with Tobin (1969) posits the ratio of the market value of the existing capital stock to its replacement cost (the " $Q$ " ratio) as the main force driving investment. Tobin argues that delivery lags and increasing marginal cost of investment are the reasons why $\mathrm{Q}$ would differ from unity. Without doubt, the neo-classical flexible accelerator theory has been the most popular. The basic notion behind this model is that the larger the gap 
between the existing capital stock and the desired capital stock, the greater a firm's rate of investment. Within the framework of the flexible accelerator model, output, internal funds, cost of external financing and other variables may be included as determinants of desired capital stock. Empirical tests of this theory using data from several countries have been extensively applied. However, salient and underlying assumptions of some theories, for example perfect capital markets and little or no public sector investment are not features of a significant number of developing countries. Furthermore, institutional and even data availability in developing countries have made it difficult for empirics to be done satisfactorily on neo-classical theory. Data on some variables like labour force, wages, and real financial rates for debt are not readily available for perusal, Zimbabwe is a typical example.

Most empirical studies on investment have confirmed theoretical arguments; Jenkins (1998) in her study on Zimbabwe found GDP to positively affect investment whilst the user cost of capital had a negative effect. The result was similar in a study of RSA by Fedderke et al (2001).Other notable findings on the negative relationship between user cost of capital and investment include that of Chirinko et al (1999). However, Badawi (2004) and Hussain et al (2002) on selected African countries deduced positive relationship between investment and interest rates, and there was such a result for Zimbabwe. Data for the study suggested support of the Mckinnon -Shaw hypothesis of repressed financial markets. On debt, Jenkins (1998) deduced that government debt in Zimbabwe had a negative effect on investment. In similar findings, Mbanga and Sikod (2001) found debt to be detrimental to investment. Supporting the same findings is Sioum (2002) on a study in Sub-Saharan Africa. Empirical evidence has also supported the neo classical theory. In addition to Jenkins' (1998) study for Zimbabwe, Perkins et al (2005) deduced similar findings for RSA that there is a positive relationship between national output and investment. Other studies as well hold the same view (for example Ndikumana, 2000, Collier and Gunning, 1999). There have also been some interesting factors proven to induce investment. Amongst these are; good tax policy (Goolsbee, 2004), Gwartney, Lawson, and Holcombe (1999); economic freedom (Vamvakidis, 1998); De Haan and Siermann (1998). Other negative factors affecting investment identified include; unexpected economic swings, Ouattara (2004); public investment, Acosta, 2005 and instability, Bigstern et al (1999). From theoretical and empirical findings in the two countries under study, variables not usually given rigor in the past studies include amongst others; uncertainty and instability. Also from the empirical literature above, the most useful work to this intended study is that of Badawi (2004) for his study that focused on Sudan. However, the study did not capture some of the valid factors explained by theory and proven by empirical studies such as debt, inflation and political instability. In the case of the two countries to be studied, these factors are likely to hamper investment and therefore rigorous analysis of them should be given attention in the investment equations. It is important that as part of the determinants of private investment that lie in the range of policy interventions, they are also analyzed to detail to improve reform measures on investment.

\section{Data and Methodology}

The data in use is sourced from the South African reserve Bank (SARB), IMF and World Bank. Variables that dominate private investment models can be grouped into financial and non-financial determinants. Financial variables include real interest rate and bank credit. The non-financial variables include government investment, terms of trade, real output, real exchange rate, inflation, debt and policy. Other recent literature has suggested that institutional factors like protection of property rights and an efficient legal system are also important determinants. The determinants of investment are therefore multidimensional. The reformulated model derives inspiration from the general model given in equation (1). The model adopts an error correction approach. As such, it eliminates spurious correlations among variables. Furthermore, using an error correction model (ECM), encompassing the cointegrated VAR technique, differentiates between longrun and short-run impacts of explanatory variables, hence providing an invaluable tool for policy analysis.

$Z_{t}=A_{0} D_{t}+A_{1} Z_{t-1}+A_{2} Z_{t-2}+\ldots \ldots \ldots+A_{k} Z_{t-k}+\epsilon_{t}$

The above is the general equation to be followed and in this equation, $Z$ is an $n .1$ vector containing all $n$ variables in the system. Included under $\mathrm{Z}$ are the variables determining investment. $D$ in this case is a vector representing deterministic terms. Here we find intercepts, trends and dummies. $\in$ is the error correction term. The reformulated model captures as well some of the economic variables, which play roles in 
determining investment behaviour in the countries, studied. Amongst such variables, we have government debt and the inflation rate. The reformulated model is thus stated:

$I_{t}=\alpha_{0}+\alpha_{1} G D P_{t}+\alpha_{2} G o v D_{t}+\alpha_{3} \operatorname{Inf}_{t}+\alpha_{4} r_{t}+\alpha_{5} I_{t-1}+\varepsilon_{t}$

$\alpha_{1}, \alpha_{2}, \alpha_{3}, \alpha_{4}, \alpha_{5}$ are the coefficients for the explanatory variables, $\alpha_{0}$ is the intercept and $\varepsilon_{t}$ is the error term at time t. $_{\text {. }}$

Where: $I_{t}=$ Gross Fixed Capital Formation as a proxy for current year private investment, $\mathrm{GDP}_{\mathrm{t}}=$ real output, as according to the accelerator theory. Empirical studies have verified the positive relationship between an economy's output and investment (Fielding 1997, Ghura and Goodwin, 2000; Ndikumana 2000 and Sioum, 2002). A higher level of aggregate output raises private investment. We therefore expect a positive relationship between $\mathrm{I}_{\mathrm{t}}$ and $\mathrm{GDP}_{\mathrm{t}}$.

$\operatorname{Gov}_{\mathrm{t}}=$ Government debt. Its effect on investment is expected to be negative since empirics have confirmed that high debt inhibits private investors' initiatives. A high debt level could be an indication of overindebtedness and might signal the lack of sustainability and viability of macro-economic policies in the long run. High government domestic debt also discourages firms to make long term investments. Jenkins (1998) on a study in Zimbabwe deduced that the debt to GDP ratio was found to be negatively affecting investment. Further than that, a country's debt obligations to the international community, empirics have revealed, can drag investment (Iyoha, 2000).

$\mathrm{Inf}_{\mathrm{t}}=$ Annual inflation rate. As an indicator of macroeconomic instability, inflation hampers investment. Also influenced by government spending, inflation spells out the level of government efficiency. According to empiral studies (Oshikoya, 1994), high and unpredictable inflation distorts the information content of relative prices and increases the riskiness of longer time investment.

$r=$ interest rate which in this case is a proxy for the user cost of capital component. Some studies have supported the neo-classical theories, and suggest a negative relationship between $r$ and $I_{t}(J e n k i n s, 1998)$. The user cost of capital is expected to negatively affect private investment (Ang, 2010). However, for some developing countries the effect of interest rate remains an empirical issue and hence can be positive (Asante, 2000; Badawi, 2004). In such cases, the data supports the McKinnon-Shaw hypothesis. McKinnon and Shaw (1973) suggest that there could be a positive relationship between investment and real rate of interest rate, because higher real rate of interest would increase savings, volume of domestic credit will increase as a result, and equilibrium investment be higher. This hypothesis, known as McKinnon - Shaw hypothesis, is based on assumption that quantity of financial resources is the main constraint on investment rather than the cost of financial resources.

$I_{t-1}=$ private investment lagged one period, which we expect to be positively related to current year private investment. The error correction representation of equation (2) can take the form:

$$
\Delta Z_{t}=A_{o} D_{t}+\Pi Z_{t-1}+\Gamma_{1} \Delta Z_{t-1}+\Gamma_{2} Z_{t-2}+\ldots+\Gamma_{k-1} \Delta Z_{t-k+1}+V_{t .} \text { (3) (Badawi, 2004) }
$$

Thus, equation (3) shows how long run impacts on elements of $Z$ are incorporated in short term dynamics or forces. There are some variables that are associated especially with both economies more so with the Zimbabwean economy, but because of data paucity could not be captured in time series methodology. From quantitative variables, we have foreign aid inflows, budget deficit, labour, the number of strikes and related disturbances to production and the real exchange rate. On the qualitative variables affecting investment we have policy uncertainty and negative perceptions about the economy, which cannot be easily quantified, as such they will be captured with a dummy variable. Under the VAR system of equations, Equation (3) is one of the equations where all variables are defined in terms of other variables and their lagged values and variables own lagged value. In an ECM, the short term dynamics of the variables in the system are influenced by the deviation from equilibrium (Enders, 2004). There is a class of models that uses a combination of first differenced and lagged levels of cointegrated variables as a way of obtaining long run solution amongst variables. Considering the model below:

$$
\Delta Y_{t}=\beta_{1} \Delta X_{t}+\beta_{2}\left(Y_{t-1}-\lambda X_{t-1}\right)+\mu_{t}
$$


The above model is known as an ECM or alternatively an error correction model. It is explained as follows. The term $Y_{t-1}-\lambda X_{t-1}$ is known as the error term. A necessary condition is that $\mathrm{Y}_{\mathrm{t}}$ and $\mathrm{X}_{\mathrm{t}}$ are cointegrated with the cointegrating coefficient $\lambda$ then $\left(Y_{t-1}-\lambda X_{t-1}\right)$ will be I(0) even though the constituents are I(1) (Brooks, 2002). It becomes valid then to use OLS and standard procedures for statistical inference on the equation above. It is also possible to have an intercept in either the cointegrating term, for example $Y_{t-1}-\alpha-\lambda X_{t-1}$ or in the model for $\Delta \mathrm{Y}_{\mathrm{t}}$ that is, $\Delta Y_{t}=\beta_{0}+\beta_{1} \Delta X_{t}+\beta_{2}\left(Y_{t-1}-\lambda X_{t-1}\right)+\mu_{t}$ or both. Whether a constant is included or not could be determined on the basis of financial theory.

\section{Presentation and Analysis of Results}

In this section we present the stationarity, cointegration and regression results for the investment demand models for both RSA and Zimbabwe. For stationarity results, the Dickey-Fuller and the Augmented DickeyFuller techniques are employed. The Johansen technique is used for Cointegration.

Table 1: Stationarity Tests

\begin{tabular}{llllll}
\hline \multirow{2}{*}{ Variables } & \multicolumn{2}{l}{ Dickey-Fuller } & \multicolumn{2}{l}{ Augmented Dickey-Fuller } & \multirow{2}{*}{ Stat. status } \\
\cline { 2 - 4 } & \multicolumn{2}{l}{ Constant } & \multicolumn{2}{l}{ Constant \& trend } & \multicolumn{2}{c}{ Constant } & \multicolumn{2}{c}{ Constant \& trend } & \\
\cline { 1 - 2 } \multicolumn{2}{l}{ Results for } & unit roots tests on levels in RSA & & & \\
LGFC & -1.1257 & -1.1199 & -1.1842 & -0.5339 & $\mathrm{I}(1)$ \\
LGDP & 1.5903 & -1.4212 & 2.3011 & -0.0650 & $\mathrm{I}(1)$ \\
LGOVD & $-1.6746^{*}$ & -1.5206 & -1.7271 & 0.4796 & $\mathrm{I}(1)$ \\
LINF & -0.1049 & $-3.5750^{* *}$ & 0.7415 & -2.0492 & $\mathrm{I}(1)$ \\
R & $-2.3194^{* *}$ & $-3.1432^{*}$ & $-2.8520^{*}$ & $3.6934^{* *}$ & $\mathrm{I}(0)$ \\
Results for & unit roots tests on first differences in RSA & & \\
DLGFC & $-2.938^{* * *}$ & $-4.054^{* * *}$ & $3.3176^{* *}$ & $-4.727^{* * *}$ & $\mathrm{I}(0)$ \\
DLGDP & $-4.551^{* * *}$ & $-6.114^{* * *}$ & $-6.924^{* * *}$ & $-3.872^{* *}$ & $\mathrm{I}(0)$ \\
DLGOVD & $-2.419^{* *}$ & $-11.17^{* * *}$ & $-11.508^{* * *}$ & $-11.75^{* * *}$ & $\mathrm{I}(0)$ \\
DLINF & $-4.958^{* * *}$ & $-5.159^{* * *}$ & $-8.781^{* * *}$ & $-8.618^{* * *}$ & $\mathrm{I}(0)$ \\
\hline
\end{tabular}

\begin{tabular}{|c|c|c|c|c|c|}
\hline \multirow[b]{2}{*}{ Variables } & \multicolumn{2}{|c|}{ Dickey-Fuller } & \multicolumn{2}{|c|}{ Augmented Dickey-Fuller } & \multirow[b]{2}{*}{ Stat. status } \\
\hline & Constant & $\begin{array}{c}\text { Constant \& } \\
\text { trend }\end{array}$ & Constant & Constant \& trend & \\
\hline \multicolumn{6}{|c|}{ Results for unit roots tests on levels in Zimbabwe } \\
\hline LGFC & -1.491 & -1.59182 & -1.3248 & -1.7470 & I (1) \\
\hline LGDP & -0.975 & -0.6144 & -1.2461 & 0.1214 & I (1) \\
\hline LGOVD & -1.506 & -2.2598 & -2.3619 & -2.4161 & $\mathrm{I}(1)$ \\
\hline LINF & 0.663 & -1.3501 & 0.5898 & -1.0104 & $\mathrm{I}(1)$ \\
\hline Lr & 0.852 & -1.0727 & 1.1444 & -0.6006 & $\mathrm{I}(1)$ \\
\hline \multicolumn{6}{|c|}{ Results for unit roots tests on first differences in Zimbabwe } \\
\hline DLGFC & $-5.05^{* * *}$ & $-6.331^{* * *}$ & $-7.046^{* * *}$ & $-6.845^{* * *}$ & $\mathrm{I}(0)$ \\
\hline DLGDP & $-6.215^{* * *}$ & $-7.109^{* * *}$ & $-5.622^{* * *}$ & $-5.480^{* * *}$ & $\mathrm{I}(0)$ \\
\hline DLGOVD & $-6.866^{* * *}$ & $-6.510^{* * *}$ & $-6.713^{* * *}$ & $-6.583^{* * *}$ & $\mathrm{I}(0)$ \\
\hline DLINF & $-6.583^{* * *}$ & $-6.513^{* * *}$ & $-7.191^{* * *}$ & $-7.092^{* * *}$ & $\mathrm{I}(0)$ \\
\hline DLr & $-4.862^{* * *}$ & $-5.497^{* * *}$ & $-5.236^{* * *}$ & $-5.631^{* * *}$ & $\mathrm{I}(0)$ \\
\hline
\end{tabular}


Table2: Johansen-Juselius maximum likelihood Cointegration Tests for South Africa

\begin{tabular}{lllllll}
\hline $\begin{array}{l}\text { Null } \\
\text { Hypothesis }\end{array}$ & Trace Test & & & \multicolumn{2}{l}{ Maximum Eigenvalue Test } \\
\cline { 2 - 7 } & $\begin{array}{l}\text { Alternative } \\
\text { Hypothesis }\end{array}$ & Statistic & $\begin{array}{l}\text { Critical } \\
\text { Value }\end{array}$ & $\begin{array}{l}\text { Alternative } \\
\text { Hypothesis }\end{array}$ & Statistic & $\begin{array}{l}\text { 95\% } \\
\text { Value }\end{array}$ \\
\hline $\mathrm{r}=0$ & $\mathrm{r} \geq 1$ & $116.737^{* * *}$ & 69.819 & $\mathrm{r}=1$ & $48.574^{* * *}$ & 33.877 \\
$\mathrm{r}=1$ & $\mathrm{r} \geq 2$ & $68.163^{* * *}$ & 47.856 & $\mathrm{r}=2$ & $35.109^{* * *}$ & 27.58434 \\
$\mathrm{r}=2$ & $\mathrm{r} \geq 3$ & $33.054^{* *}$ & 29.797 & $\mathrm{r}=3$ & & \\
\hline
\end{tabular}

Cointegrated variables ensure that we eliminate spurious relations and as such share common stochastic trends. Further than that, they enable us to formulate an error correction model as we determine the long-run relationship among the variables.

Table 3: Johansen-Juselius maximum likelihood Cointegration Tests for Zimbabwe

\begin{tabular}{lllllll}
\hline $\begin{array}{l}\text { Null } \\
\text { Hypothesis }\end{array}$ & Trace Test & & & \multicolumn{2}{c}{ Maximum Eigenvalue Test } \\
& $\begin{array}{l}\text { Alternative } \\
\text { Hypothesis }\end{array}$ & Statistic & $\begin{array}{l}\text { Critical } \\
\text { Value }\end{array}$ & $\begin{array}{l}\text { Alternative } \\
\text { Hypothesis }\end{array}$ & Statistic & $\begin{array}{l}\text { 95\% Critical } \\
\text { Value }\end{array}$ \\
\hline $\mathrm{r}^{1}=0$ & $\mathrm{r} \geq 1$ & $142.228^{* * *}$ & 69.819 & $\mathrm{r}=1$ & $83.958^{* * *}$ & 33.877 \\
$\mathrm{r}=1$ & $\mathrm{r} \geq 2$ & $58.27^{* * *}$ & 47.856 & $\mathrm{r}=2$ & $29.776^{* *}$ & 27.584 \\
\hline
\end{tabular}

${ }^{* * * * * * *}$ denotes significant statistic at $1 \%$ and $5 \%$ levels of significance.

The null hypothesis that there is no cointegrating vector is rejected since both the maximum Eigen Value and trace statistics are greater than their respective critical values from the Johansen tables. We therefore conclude that there are two cointegrating vectors for both RSA and Zimbabwe.

Table 4: Regression results on determinants of private investment in RSA and Zimbabwe

\begin{tabular}{|c|c|c|c|c|c|c|}
\hline \multirow[b]{2}{*}{ Variable } & \multicolumn{3}{|c|}{ RSA } & \multicolumn{3}{|c|}{ Zimbabwe } \\
\hline & Coefficient & t-value & Prob. & Coefficient & t-value & Prob. \\
\hline Constant & 0.090870 & $1.6^{*}$ & 0.050921 & -0.006829 & -0.24 & 0.8153 \\
\hline DLGFCF_2 & - & - & - & 0.469991 & $2.44^{* *}$ & 0.0275 \\
\hline DLGDP_1 & 1.411385 & $2.35^{* *}$ & 0.0296 & - & - & - \\
\hline DLGDP_2 & - & - & - & 0.892978 & $1.86^{*}$ & 0.0821 \\
\hline DLGovD & -0.316415 & -1.61 & 0.1228 & -0.220300 & $-3.73^{* * *}$ & 0.0020 \\
\hline DLGovD_2 & - & - & - & -0.093686 & -1.63 & 0.1244 \\
\hline INF & -0.042513 & -1.59 & 0.1278 & - & - & - \\
\hline INF_2 & - & - & - & -0.166443 & $-2.61^{* *}$ & 0.0198 \\
\hline $\mathbf{r}$ & - & - & - & 0.127809 & 1.51 & 0.1520 \\
\hline $\mathbf{r}_{-} \mathbf{t}-2$ & -0.290751 & $-2.68^{* *}$ & 0.0149 & & & \\
\hline DUM$_{1999}$ & - & - & - & -0.194138 & -1.62 & 0.1263 \\
\hline ECT_1 & -0.290751 & $-2.10^{* *}$ & 0.0498 & -0.499115 & $-2.84^{* *}$ & 0.0125 \\
\hline
\end{tabular}

\footnotetext{
${ }^{1} \mathrm{r}$ represents the number of cointegrating vectors
} 


\section{Diagnostic Statistics}

$\begin{array}{lcc}\text { Sigma } & 0.049454 & 0.115992 \\ \text { RSS } & 0.046468 & 0.201812 \\ \mathbf{R}^{\wedge 2} & 0.671305 & 0.725044 \\ \text { F } & 7.760874 & 4.944274 \\ \text { Prob(F-Statistic) } & 0.000401 & 0.003842 \\ \text { Log-likelihood } & 43.12499 & 23.28713 \\ \text { DW } & 1.55 & 1.66 \\ \text { Mean(DLGFC) } & 0.001760 & -0.018134 \\ \text { S.D(DLGFC) } & 0.076749 & 0.178640\end{array}$

A number of simulations were performed for the estimated equations for both countries. Both models are generally robust. The signs are in agreement with theoretical postulations. The conventional tests of the model diagnostics such as $\mathrm{R}^{2}$, F statistic and the standard error confirm the strength of the models. It was also necessary to consider the statistical properties for both models. Both models were tested for autocorrelation, autoregressive conditional heteroskedasticity, normality, heteroskedasticity and specification error test (RESET). The results suggest that the models are well specified. The diagnostics indicate that the residuals are normally distributed, homoskedastic and serially uncorrelated. The fitted and actual values and the scaled residuals add validity to the models ${ }^{2}$. RSA's annual output, has a positive effect on investment. The coefficient suggests that a $1 \%$ increase in GDP will increase the investment by $1.4 \%$. Thus an increase in gross domestic product will increase the nation's investment levels. Therefore, to maintain the current growth in investment, the country has a challenge to grow the national output, which will positively affect investment in the subsequent year. RSA has recorded steady growth in annual output over the years; the result comes as no surprise to the high private investment levels in the country. Though the FIFA 2010 ended, the benefits accruing thereof will likely impact on investment in the long term. However, current low GDP growth rates confirm a weak economy as a result of weak global demand, competitiveness challenges facing the manufacturing sector, which shrunk 7.9\% year on year by the first quarter of 2013 .

For Zimbabwe, results reveal that 1\% increase in GDP two years back positively affects current year investment by $0.9 \%$. This score on the importance of GDP on investment. With a downward trend for almost a decade due to the unstable socio-economic environment, a lot has to be done to restore confidence in the economy spheres in Zimbabwe. The current environment under the leadership of the Government of National Unity (GNU) scored promising levels with GDP growth estimated at around 5\% in 2010 and firms looking set to commit themselves in investment, ending a decade of economic woes. With the country's elections anticipated by year end, uncertainty shrouds investment and GDP growth. As for government debt, theory has postulated a negative relationship with investment. In the case of RSA, the government debt sign bears the expected negative sign, pointing towards the possibility of crowding investment. However, this is insignificant. This suggests that RSA government debt is maintained within sustainable levels. The historical trend of government debt has been at manageable levels, which did not crowd out private investment. In the estimated Zimbabwean investment demand model scenario, results show that government debt is significant at $1 \%$. The coefficient for this variable suggests that a $10 \%$ increase in Government debt will reduce the country's investment by over $2 \%$. With the high levels of government domestic debt, the results serve as an omen of the situation prevailing in the country during the study period. It is therefore inevitable that investment has been declining as mounting government debt has crowded out private investment. The money was used mainly to cater for the country's huge civil servants wages as mounting inflation took its toll.

\footnotetext{
${ }^{2}$ The actual and fitted values for GFCF for both countries are shown in the appendices.
} 
Other contributors to this debt have been the parliamentary elections, senate related expenditure, unbudgeted compensation to pay liberation collaborators and mounting interest and debt payments to domestic and the international community. The other reason for the high government debt is that since the government had sour relations with external borrower's post 1999, there was heavy reliance on the domestic market to source funds. Use has been made of Treasury Bills. With lending rates at one time exceeding $800 \%$ and inflation level reaching an all time high of 200 million\% in 2008. This confirms the levels of government debt and the resulting negative feeds on investment.

The inflation rate, as an indicator for macroeconomic instability bears the correct negative sign for RSA. The coefficient suggests that a $10 \%$ increase in the inflation rate will shrink investment by $0.4 \%$. This could be the case citing inflation targeting in the country. The monetary authorities have done commendable work to keep prices within the stipulated band. This has contributed to business confidence as investors have been aware of the economy's inflation anticipations and measures to reign on as it enables investors to make plans when deciding expenditures as they have certainty that prices will not fluctuate wildly. The current economic outlook portrays a weak economy with a depreciating rand, high oil, input and food prices, all of which can weigh down on investment as they fuel inflation. Zimbabwe's inflation rate is significant at $5 \%$. Current investment levels are negatively influenced by inflation levels two years back. This worsens the impact of government debt on investment. With a majority of businesses relying on imports of fuel and its products for daily operations, foreign currency shortages dealt a big blow to the viability of their businesses. Some businesses had to resort to sourcing foreign currency for importing fuel from the black market. This led most of them to pass on the high operating costs to the final consumer of their products, hence inflation. Others still, whilst importing raw materials resorted to the black market for foreign currency and again, the final consumer being at the receiving end in terms of high prices paid on goods and services. Pressure from the workers unions also added to the inflation cake as salaries spiralled due to high prices of basics as workers sought to be cushioned accordingly. The coefficient of the user cost of capital is negative and significant for RSA at $5 \%$. Increasing interest rates by $10 \%$ decreases investment by almost $3 \%$. This confirms how sensitive investment is to interest rates, more so now when the global economy is fresh from the recent recession. Developed countries have pursued very low interest rates all in an effort to boost investment levels. For example, Japan has maintained interest rates at $0.1 \%$. Current interest rates in RSA are at low levels necessary to boost investment levels whilst at the same time maintaining the reign on inflation. For Zimbabwe the user cost of capital is positive though insignificant. Some empirical studies for developing countries have found interest rates to be positively related with investment (Badawi, 2004; Hussain et al, 2002). The sign of the interest rate is also an empirical issue and depends on whether the data support the McKinnon-Shaw hypothesis or the neoclassical model. The McKinnon-Shaw hypothesis deals with the deposit rate but the lending rate is highly and positively correlated with the deposit rate.

This may be due to the fact that there was a spell period where interest rates were controlled in Zimbabwe, fitting the description of a financially repressed system. This is a valid assertion as the real interest rate in Zimbabwe was below the equilibrium level for some of the periods under study. This scenario of controlled interest rates discouraged savers, most of whom opted to transfer their monies to the equity market whilst some preferred locking their funds in property. As a result, investment was negatively affected. Investment lagged two years affects current investment levels in Zimbabwe. This could suggest that firms are backward looking in their decision to commit to current year investments. The dummy variable for Zimbabwe is negative. This is expected as farm invasions peaked in 1999. This caused uncertainty on property rights and hence some firms were no longer willing to commit much on fixed property. The models were also subject to structural breaks test to determine changes during the study period. ${ }^{3}$ SA's stability diagnostics tests indicate a structural break in 2008 during the global recession. The stability tests carried out indicate structural break for Zimbabwe as well, with the years of interest being 2001 and 2002, the years marking the height of land reform programme and the disputed presidential elections, which were both, marred with violence in this agricultural economy.

The error correction term indicates the speed of the equilibrium restoring adjustment in the dynamic model. The ECM coefficient shows how quickly/slowly variables returns to equilibrium and it should have a

\footnotetext{
${ }^{3}$ Graphs for structural breaks are presented in the appendix
} 
statistically significant coefficient with a negative sign. Bannerjee et al. (1998) holds that a highly significant error correction term is further evidence of a stable long-run relationship. The error correction term for RSA carries a negative sign that suggests a non-explosive situation. The speed of adjustment is approximately $29 \%$. This implies that in one year approximately $29 \%$ of the deviations from the long run equilibrium are eliminated in the following year. The result of the error correction term further suggest that there are other factors inhibiting investment in the RSA economy but could not be revealed in this study. A further study is therefore imperative, with the sole aim on deducing some other constraints retarding the growth of investment in the country. For Zimbabwe, the error correction term carries a negative sign that also suggests a non-explosive situation as well. The speed of adjustment is approximately $49.9 \%$. This implies that in one year approximately $49 \%$ of the deviations from the long run equilibrium are eliminated in the following year.

\section{Conclusion and Policy Recommendations}

From theoretical foundations and empirical research done for most developing countries, this study has investigated the determinants of private investment in RSA and Zimbabwe in the period 1980-2010. By employing econometric techniques such as stationarity, cointegration and error correction models, the study aimed to find robust models for providing information, which can be used in policy formulation, and to boost private sector investment in the two countries. From the study, the factors that had significant effect on investment in RSA are output, government debt and the interest rates. For Zimbabwe output, government debt, inflation, prior year investment and a host of socio-economic factors.The financial market in Zimbabwe during the period of study exhibited evidence of a repressed financial market. As such, due to low interest rates, savers preferred to lock their funds in stock, thus leaving the banks with insufficient funds for lending investors for expanding their fixed capital base.

The main policy recommendations that may be inferred from these results are as follows:

The policy of pursuing economic growth and low interest rates would be useful in attracting private investment in RSA. It is also essential for government debt to be maintained at a sustainable level as is currently practised. Though much can be pointed on the weak global economy, RSA has a share in contributing to suboptimal performance on the export front, which has a bearing on investment. According to the Manufacturing Circle ( a body which interacts with government and other stakeholders in order to review, debate and help formulate policies which will have a positive impact on South Africa's manufacturing base), there are other export inhibiting factors in the country like; energy and labour costs, labour instability and infrastructure system. All these weigh down on competitiveness. If exports are to improve, these factors will have to be addressed and thereby enhancing investment as well. Furthermore, addressing these will ensure that the economy reigns on the unfavourable budget deficit.

Zimbabwe should lean more on measures to ease the private sector's financial constraints and as such should promote credit expansion. The authorities have to come with policies to reign in on inflation so as to raise business confidence in the economy. In addition, to consider on policy is the high government debt which crowds out private investment. The economy also faces anti competitiveness factors in the form of policy uncertainty, domestic political uncertainty, legal and regulatory system and even health care system. There are also other factors affecting investment in the study period but could not be captured due to data paucity. As examples; legal system, property rights, civil unrest, and strikes. Apart from these, it will also be important for the governments of both countries to give a clear path about the future of carbon tax. This will go a long way in informing on long-term investment decisions on the part of firms. Since the study focused on selected macroeconomic variables determining investment, this entailed omitting other macro pointers such as foreign aid, the current account balance, the real exchange rate and the budget deficit that can be considered vital in other similar research areas. Some of these variables may be misleading as indicators of the macroeconomy especially for Zimbabwe, considering the current political and socio-economic difficulties confronting the country. Another useful extension of the present study would also be to empirically examine the effect of private investment on economic growth, unemployment and poverty reduction for both countries. 


\section{References}

Acosta, P. (2005). Short Run and Long Run Determinants of Private investment in Argentina. Journal of Applied Economics, 8(2), 389-406.

Ang, J. B. (2010). Determinants of Private Investment in Malaysia: What causes the post crisis slump? Contemporary Economic Policy, 28(3), 378-391

Asante, Y. (2000). Determinants of private investment in Ghana. Nairobi, African Economic Research Consortium.

Badawi, A. (2004).Private Capital Formation and Macroeconomic policies in Sudan: Application of a simple cointegrated vector autoregressive model. Department of Economics, University of Khartoum

Bannerjee, A., Dolado, J. \& Mestre, R. (1998). Error-correction Mechanism Tests for Cointegration in Single Equation Framework. Journal of Time Series Analysis, 19, 267-283.

Bigsten, A., Bigstern, A., Collier, P., Dercon, S., Gauthier, B., Gunning, J. W., Isaksson, A., Oduro, A., oostendorp, R., Patillo, C., Soderbom, M., Sylvian, M., Teal, F. \& Zeufack, K. (1999). Investment in Africa's manufacturing sector: A four country panel data analysis. Oxford Bulletin of Economics and Statistics, $61(4)$.

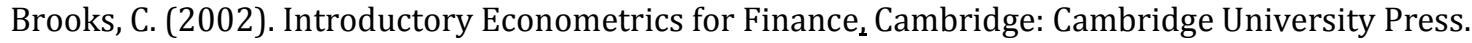

Chirinko, R., Fazzari, S. \& Meyer, A. (1999). How responsive is business capital formation to its user cost? An explanation with micro data. Journal of Public economics, 74, 53-80

Collier, P. \& Gunning, J. (1999).Explaining African economic performance . Journal of Economic Literature, 37 (1), 64-111.

De Haan, J. \& Siermann, C. L. (1998). Further evidence on the relationship between economic freedom and economic growth. Public choice, 95, 363-80

Dickey, D. \& Fuller, W. A. (1979). Distribution of the estimators for time series regressions with a unit root. Journal of the American Statistical Association, 74, 427-431

Enders, W. (2004). Applied econometric time series, second edition, John Wiley and Sons, Inc.

Fedderke, J. W., Kayemba, J. S., Henderson, S., Mariotti, M. \& Vaze, P. (2001). Changing factor market conditions in South Africa: the capital market- a sectoral description of the period 1990-97. Development South Africa, 18(4).

Fielding, D. (1997). Adjustments, Trade Policy and Investment Slumps: Evidence from Africa. Journal of development Economics, 1(2).

Ghura, D. \& Goodiwin, B. (2000). Determinants of private investment: A cross-regional empirical analysis. Applied Economics, 32(14), 1819-1829.

Goolsbee, A. (2004). The impact of the corporate income tax: Evidence from state organizational form data. Journal of public economics, 88, 2289-2299.

Gwartney, J. D., Lawson, R. A. \& Holcombe, R. G. (1999). Economic freedom and environment for economic growth. Journal of Institutional and Theoretical Economics, 155, 643-63.

International Monetary Fund. (2010). IMF Statistics online. available at http://www.imfstatistics.org/imf/ (Accessed 23-04-2011)

Hussain, M. N., Mohammed, N. \& Kameir, E. M. (2002). Chapter 11 Resource Mobilisation, Financial liberalisation, and Investment. The case of some African countries. (available on line, www.idrc.ca/openebooks/888-0/\#page_379

Iyoha, M. (2000). An Econometric Analysis of External Debt and Economic Growth in Sub-Saharan African Countries in External Debt and Capital Flights in Sub-Saharan Africa. Eds S.I. Ajayi and M.Khan. Washington, DC: IMF.

Jenkins, C. (1998).Determinants of Private Investment in Zimbabwe. Journal of African Economies, Oxford University Press, 7(1), 34-61.

Johansen, S. (1991). Estimation and Hypothesis Testing of Cointegrating Vectors in Gaussian Vector Autoregressive Models. Econometrica, 59, 155-80

Jorgenson, D. W. (1971). Econometric studies of investment behaviour. Journal of Economic Literature, December.

Manufacturing Circle (2013). Available on line at http://www.manufacturingcircle.co.za/quarterly_bulletins.html (accessed 30-04-2013). 
Mbanga, G. N. \& Sikod, F. (2001).The Impact of debt-service payments on investments in Cameroon. A final report to be presented at the AERC Biannual research Workshop at the Grand regency Hotel in Nairobi, May 26-31, 2001.

Mckinnon, R. I. (1973). Money and capital in economic development. Washington D.C.: The Brookings institute.

Ndikumana, L. (2000). Financial determinants of domestic Investment in Sub-Saharan Africa. World development, 28(21), 381-400.

Oshikoya, T. W. (1994). Macroeconomic determinants of Domestic Private Investment in Africa: An empirical analysis. Economic Development and cultural change, 42(3), 573-596.

Ouattara, B. (2004). Determinants of Private Investment, School of Economics Studies, University of Manchester, Manchester M13 9PL.

Perkins, P., Fedderke, J. \& Luiz, J. (2005). An analysis of Economic infrastructure Investment in South Africa, South African Journal of Economics, 73(2), 211.

Shaw, E. S. (1973). Financial deepening in Economic Development. New York: Oxford university press.

Sioum, A. S. (2002). Private investment and public policy in Sub-Saharan Africa: An empirical analysis. Working paper no. 36, The Netherlands, The Hague: Institute of social studies.

Statistics South Africa (Stats SA). (2013). Available on line at http://www.statssa.gov.za/default.asp (accessed 01-05-2013)

Tobin, J. (1969). A General Equilibrium Approach to Monetary Theory. Journal of Money, Credit and Banking, $1(1), 15-29$.

Vamvakidis, A. (1998). Explaining investment in the WAEMU. IMF Working paper no 99. Washington DC: International Monetary Fund.

World Bank. (2013). Available on line at http://data.worldbank.org/indicator/NY.GDP.MKTP.CD (accessed 01-05-2013)

World Resource Institute. (2010). Earthtrends. Available at http://earthtrends.wri.org/searchable_db/index.php?theme=5 (accessed 23-04-10)

\section{Appendices}

Appendix A: Actual versus fitted values and scaled residuals for RSA

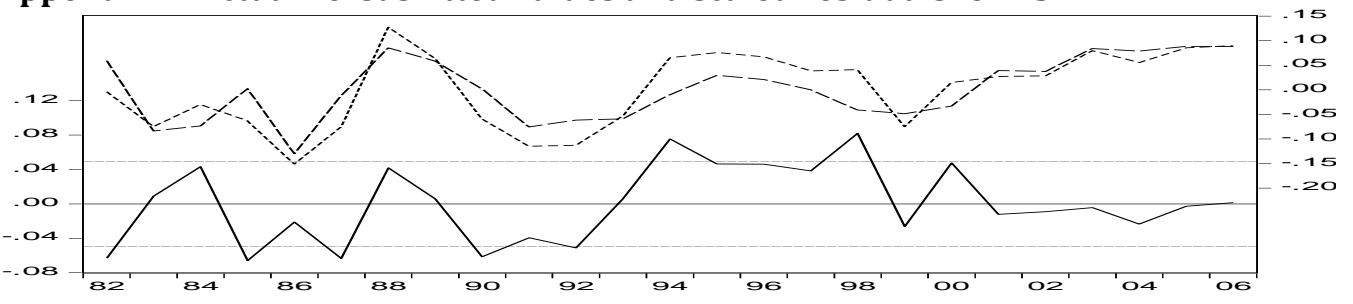

Cresidual ----- Actual --- Fitted

Appendix B: Actual versus fitted values and scaled residuals for Zimbabwe

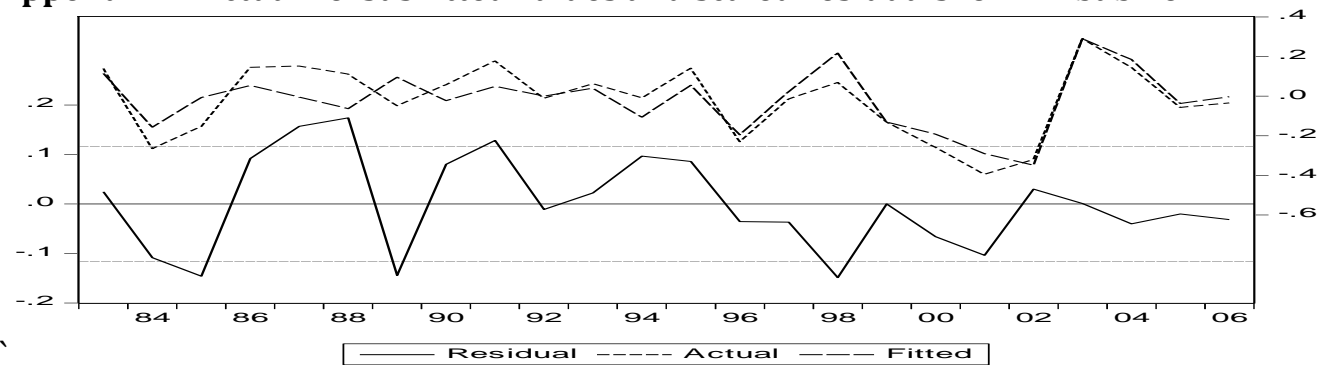


Appendix C: Stability diagnostic tests for South Africa

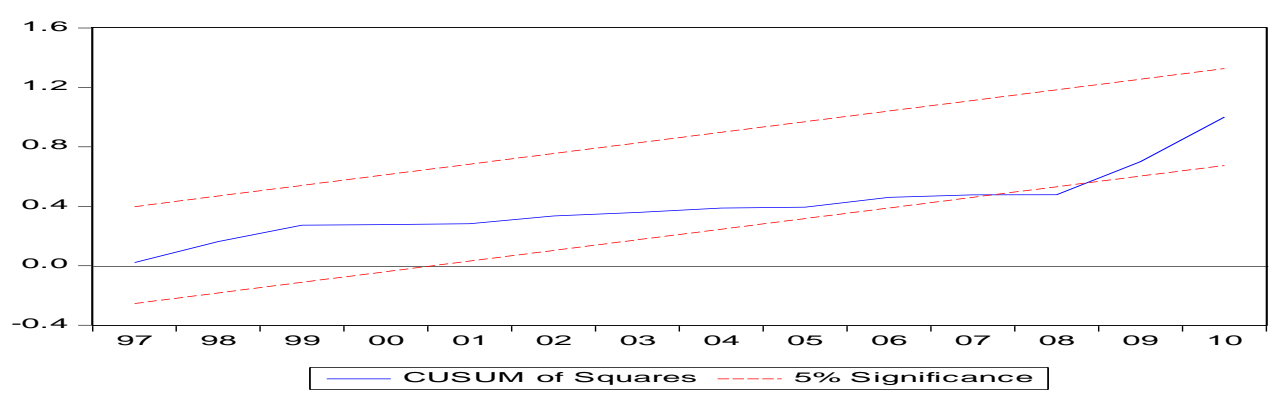

Appendix D: Stability diagnostic tests for Zimbabwe

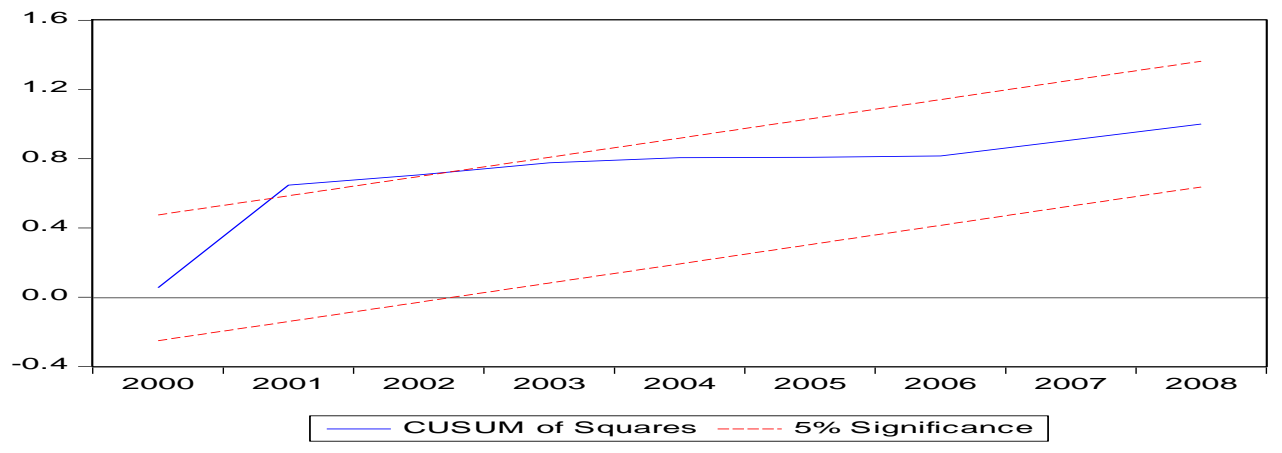

